\title{
Histopathological Effect of the Different Concentration of Crude Oil and Its Products on the Gill Apparatus of Catfish (Heterobranchus bidorsalis)
}

\author{
Ugbeyide Juliet Avwerosuoghene ${ }^{1, ~ *, ~ N w a m b a ~ H e l e n ~}{ }^{2}$ \\ ${ }^{1}$ Department of Biological Sciences, Edwin Clark University, Kiagbodo, Nigeria \\ ${ }^{2}$ Department of Applied Biology, Enugu State University of Science and Technology, Enugu, Nigeria \\ Email address: \\ jullyakpo2000@yahoo.com (U. J. Avwerosuoghene), nwambahelen@yahoo.com (N. Helen) \\ ${ }^{*}$ Corresponding author
}

\section{To cite this article:}

Ugbeyide Juliet Avwerosuoghene, Nwamba Helen. Histopathological Effect of the Different Concentration of Crude Oil and Its Products on the Gill Apparatus of Catfish (Heterobranchus bidorsalis). Ecology and Evolutionary Biology. Vol. 6, No. 2, 2021, pp. 47-52.

doi: $10.11648 /$ j.eeb. 20210602.14

Received: June 1, 2021; Accepted: June 17, 2021; Published: June 26, 2021

\begin{abstract}
This project is aimed at assessing the Histopathological effect of the different concentration of crude oil and its products on the gill apparatus of catfish (Heterobranchus bidorsalis). Three concentrations (1.0, 3.0 and $5.0 \mathrm{M} / \mathrm{L}$ ) of the petroleum products Premium Motor Spirit (PMS), Dual Purpose Kerosene (DPK) and Bonny-Light Crude oil (BLCO) were made. To each concentration, three adults of $H$. bidorsalis were incubated for 1, 24 and 96 hours. Triplicate values of samples were recorded in each of the different concentration of petroleum products. Three plastic containers containing three fishes each were not contaminated with petroleum product and was left as control $(0.0 \mathrm{M} / \mathrm{L})$ for the experimental work. Histology of the gill was used to determine the pathology of petroleum products on the gills. Histopathological examination following exposure to petroleum products showed elongation of gill lamellae, hyperplasia of lamellae, fusion of lamellae tips, separation of respiratory epithelium with underlying supporting tissue and altered gill rakers. Microscopical observation showed a significant difference $(\mathrm{P}<0.05)$ in hyperplasia and elongated gill lamellae. There were no significant difference $(\mathrm{P}>0.05)$ in heartbeats, weight and underlying supporting tissue in the different concentration of petroleum products. The various biological responses and changes observed with such histological alterations can be used as a tool to detect toxic effects of pollutants in the organs of living organism making it a good environmental stressor indicator for bioassay.
\end{abstract}

Keywords: Histopathology, Petroleum Products, Gills, Crude Oil, Heterobranchu bidorsalis

\section{Introduction}

Petroleum and its products have been recognized as a potential environmental contaminant since shortly after the beginning of the twentieth century [1]. The degree of hazardous effect of petroleum products (PPS) is dependent on the degree of their concentration, chemical components and solubility in water. An example of such effects is the distortion of gill apparatus in Heterobronchus bidorsalis fish [2]. Oil pollution is the release of petroleum products into the aquatic environment and pollution is a major disaster that affects aquatic life [3] which also causes massive destruction to economically important aquatic organism like $H$ bidorsalis [4].

\subsection{Heterobronchus bidorsalis}

H. bidorsalis is a known catfish, generally recognized by the barbells on each side of the mouth which mimics the whisker of a cat and thus the name "Cat fish". This group of fish is extremely large and diverse. They are generally grouped under a single order-Siluriformes [5]. This order is made up of 31 families and $H$. bidorsalis belong to the family Clariidae (air breathing cat fish) [5]. They are members of the class Actinopterygia (ray finned fish). There are 400 genera with approximately 2200 species in the family [6]. The habitat of this catfish is fresh water ranging from cool swift running mountain streams to still water, low land lakes and ponds [5]. H. bidorsalis is a highly esteemed group of 
fishes in tropical Africa. It commands high market value hardly in nature possesses air-breathing organs that enables it tolerate aquatic condition [7]. H. bidorsalis is equipped with a special respiratory organ known as the gills. The gill plays a vital role in the fish since they are the main site for gaseous exchange as well as partially responsible for osmo-regulation, acid bases balance and taste [8]. The gill of aquatic organize is the primary target of disturbance by petroleum product. The morphological change is a consequence of environmental changes [9] also an adaptive attempt in conserving some physiological functions [10].

\subsection{Aquatic Oil Pollution}

Pollution is made available under certain environmental conditions, thus resenting a source of diffuse pollution in the water compartment [11]. The toxicity bioassay together with physiological and chemical analysis used to detect and quantify the petroleum substance present in water ecosystem allows the assessment of the effect of toxic agent on the environment [12]. Acute effects, such as mortality and immobility in short exposure time as well as chronic effect, detected in longer exposures, are important tools for the assessment of pollution effects on the structures of communities [11]. The effects of petroleum products on the gills can be assessed by population studies particularly through the evaluation of the death and survival success [13]. Oil pollution makes breathing difficult for fishes and may even lead to their starvation and death [14]. This was seen in the behavioral response of $M$. Roosevelt when exposed to $7 \mathrm{ppm}$ lethal does and it is possible therefore to trace a parallel among the hyperplasia and the behavioral effect of intoxicated fishes [14]. The gills of fishes represent the primary target of disturbance of pollutants as they are in direct contact with the external medium to perform gaseous exchange [15]. This organs has linking sites to promote its regular functions and these sites may link to toxic substance with differentiated charges, triggering mechanical responses and toxic effects to the fish [16].

\subsection{Eco-toxicological Effects}

The 96 hours of $\mathrm{LC}_{50}$ value for an accommodated fraction of fuel oil ranged from 3.2 to $56 \mathrm{mg} / \mathrm{l}$ in fish [17]. However there can be long-term effect from these exposures such as historical damages of the organs. According to Kiihnhold [18] damage caused by oil pollution are both significant and diverse. Such pollution can destroy or limit marine life, contaminates water supplies and create fire hazard [19]. Pollution causes damages in the pillar cells of fish gills [20]. Such cellular damages are often associated to high dose in which the animals are close to death [20]. Karlsson-Norrgren and Runn [21] verified an increase in the volume of the secondary lamellae of Danio rerio, filling in the inter-lamellar space, staring from concentration $10 \mathrm{ug} / \mathrm{I}$, resulting in the decrease of the diffusion capacity. Assessing the effect in adult Dania rerio females, verified that within 24 hours the products had already been incorporated by the gill, skin and parts of the tracts.

According to Ewald, [22], tissue alterations are preceded by biochemical and physiological responses and once the damage is detected the adverse effect on the organism are incontestable. Mallrat [23] in his studies verified that the most common lesions were necrosis, hyperplasia, hypertrophy and rupture of gill tissues, lamella fusion, hyper secretion and proliferation of mucous cells, alterations in chloride cells and vascularization. According to Peleksic, and Mitrovic-Tutundizic [24], there are three phases of gill alterations where there is progressive worsening of the lesions. The first phase is when the damage may be reversed under satisfactory conditions for organism. In the second phase, the lesions are more severe and difficult to reveres. In the third phase the separation of the gill structure is irreversible, jeopardizing its vital functions and eventually causing the organism to die [24].

The current study is aimed at investigating the acute toxicological effect of the water soluble fractions of Crude oil, Premium Motor Spirit (PMS) and Kerosene (DPK) on the gill apparatus of catfish (Heterobranchus bidorsalis) adult. It seeks to provide some needed toxicological data on the Crude oil, Premium Motor Spirit (PMS) and Kerosene (DPK) that is commercially used in Nigeria especially on a common tropical fish $H$. bidorsalis. To determine the petroleum products that has the greatest effect on the gill apparatus of $H$. bidorsalis.

\section{Materials and Methods}

One hundred and eleven (111) adults of Hetrobronchus bidorsalis with mean weight of $163.2 \pm 1.00 \mathrm{~g}$ were transported from a private fish hatchery at Ugwuomu Emene in Enugu State Nigeria to the Phenoma Farms Head Quarters Ngwo Enugu State. These adult fishes were in one plastic container of $200 \mathrm{~L}$ and the water temperature was maintained at $23 \pm 1.0^{\circ} \mathrm{C}$ during transportation. The fishes were acclimatized for 14 days and were maintained on a $38 \%$ crude protein diet at $3 \%$ body weight.

\subsection{Experimental Oil Products}

Three samples of crude oil and its products were used for this study; these were Bonny-Light-Crude Oil (BLCO), Premium Motor Spirit (PMS) and Dual Purpose Kerosene (DPK). Aliquot of each of these three oil samples were introduced in triplicate to 27 plastic containers $(90 \mathrm{~L})$ at concentration 1.0, 3.0 and 5.0 $\mathrm{M} / \mathrm{L}$. Three plastic containers with fish were not contaminated with any oil samples $(0.0 \mathrm{M} / \mathrm{L})$ and were left stocked in Completely Randomized Block Design (CRBD) in 30 plastic containers $(90 \mathrm{~L})$ at 3 fish per container. Each container was then filled to $50 \mathrm{~L}$ mark with water.

\subsection{Experimental Treatment}

Two experimental periods were adopted for the study: the toxicity period, which lasted for 1 hour (60 minutes) and the recovery period of 24 hours (1440 minutes) and 96 hours' (5760 minutes) was monitored at daily internals. At the end of the toxicity period, the surviving fishes and the containers were washed thoroughly with clean water to allow for 24 and 96 hours recovery period to commence.

Heart beast of fish was counted per minutes during each experimental period. This is done by sectioning the fish 
through the ventral side form the anal opening and lifting the liver by holding it with forceps there by exposing the beating heart. Mortality rate, feeding and swimming activities were observed $\mathrm{m}$ the experimental periods. Fish sample was dissected using scissor, razor blade, dissecting board, forceps etc. The heartbeats were recorded per minutes and the gills cut off from the fish and preserved in $10 \%$ formalin.

\subsection{Histopathology of Gill}

The gill was obtained by chopping, off the opercula bone from the ventral side there by exposing them. The gills were dissected, out, placed in a sample bottle containing physiological saline serving as preservatives. The Histopathological examination of the gills was carried out at UNTH Histopathological laboratory Enugu Nigeria. In the laboratory triplicates treatments of crude oil and its products and control were analyzed for the gills pathological parameters using methods as follows:

The specimen from $10 \%$ formalin was processed with automatic tissue processor. The reagents used include alcohol, which removes water from the tissue. Xylene removes alcohol debris and fat from the tissue. Paraffin wax for impregnation and also removes Xylene from tissue.

\subsection{Histopathological Filtration}

This process involved filtering three beakers of large size with absolute alcohol of 70, 90 and 95\% respectively. Three other beakers of the same size were filled with Xylene, which does not need dilution. Another three beakers were filled with Paraffin wax. The specimens were passed through these three reagents sequentially. The tissues were then trimmed, mounted on a wooden block, sectioned with microtome and place on a slide and stained with Hematoxylin and Eosin stain. The prepared slides were taken to Applied Biology Laboratory, Faculty of Applied Natural Science, Enugu State University of Sciences and Technology (ESUT) and observed under 100 power magnification of an electric binocular microscope.

\subsection{Histopathological Findings}

Structural alterations and abnormalities such as elongation of gill lamellae, fusion, separation of respiratory epithelium with underlying supporting tissue, necrosis and hyperplasic of lamellae were observed [25].

\subsection{Statistics Analysis}

The statistics analysis of this work was carried out using Analysis of variance (ANOVA) method to determine whether there were significant differences between the treated and the control gill samples in the different concentration of petroleum products used.

\section{Results}

Table 1 shows mean \pm S. E of heartbeat per minutes and weight of Heterbronchus bidorsalis adult exposed to different concentration $(\mathrm{M} / \mathrm{L})$ of crude oil and its products at 1, 24 and 96 hours. The range of value for heartbeat was 96.7 to $66.3 \mathrm{beat} / \mathrm{minutes}$ while the range for weight was 162.3 to $81.2 \mathrm{mg}$. The highest value for the weight was recorded I M/L (163.2g) in DPK at 1 hour exposure and the least value was recorded in $5 \mathrm{M} / \mathrm{L}(81.2 \mathrm{~g})$ in PMS at 96 hour exposure. There was no significant difference $(\mathrm{p}>0.05)$ in the heartbeats and weight of the fish ( $H$. bidorsalis) in the different concentration of petroleum products used.

Table 2 shows mean + S. E of fused gill apparatus of Heterbronchus bidorsalis exposed to different concentration (M/L) of crude oil and its products. The range of value for PMS was 32.3 to $2.3 \mathrm{mg}$. The highest value was recorded in 5 $\mathrm{M} / \mathrm{L}$ (32.3 $\mathrm{mg}$ in altered fine branches of supporting tissues) and the least value was recorded in $1 \mathrm{M} / \mathrm{L}(2.3 \mathrm{mg}$ fused lamellae tips). The range of value for DPK was 28.7 to $1.3 \mathrm{mg}$. The highest value was recorded in $5 \mathrm{M} / \mathrm{L}(28.7 \mathrm{mg}$ in altered fine branches of supporting tissues) and the least value was recorded in $1 \mathrm{M} / \mathrm{L}$ (1.3 $\mathrm{mg}$ fused lamellae tips). The range of value for BLCO was 33.3 to $2.7 \mathrm{mg}$. The highest value was recorded in $5 \mathrm{M} / \mathrm{L}(33.3 \mathrm{mg}$ in altered fine branches of supporting tissues) and the least value was recorded in $1 \mathrm{M} / \mathrm{L}$ (2.7 mg fused lamellae tips). The analysis of variance showed significant effect $(\mathrm{P}<0.05)$ in the fused gill apparatus of the different concentration in M/L of PMS, DPK and BLCO used.

Figures 1, 2 and 3 shows percentage increase in size of the underlying supporting tissues of the gill of $H$. bidorsalis exposed to different concentrations $(\mathrm{M} / \mathrm{L})$ of petroleum products. The range of value was 70 to $10 \%$. The highest value was recorded in $5 \mathrm{M} / \mathrm{L}(70 \%)$ in $\mathrm{BLCO}$ while the least value was recorded in $1 \mathrm{M} / \mathrm{L}$ significant $(10 \%)$ in DPK. There was no significance $(\mathrm{P}>$ 0.05 ) between the concentrations of petroleum product in the underlying supporting tissue of the exposed gill.

Table 1. Means $\pm S$.E of heartbeats and weight of H. bidorsalis exposed to petroleum products.

\begin{tabular}{|c|c|c|c|c|c|c|c|c|c|c|c|c|}
\hline $\begin{array}{l}\text { Time } \\
\text { (H) }\end{array}$ & $\begin{array}{l}\text { Concentration } \\
(\mathrm{M} / \mathrm{L})\end{array}$ & $\begin{array}{l}\text { H. B }(X \pm S \text {. } \\
\text { E) }\end{array}$ & $\begin{array}{l}\text { Weight } \\
(X \pm \text { S. E) }\end{array}$ & $\begin{array}{l}\text { PMS } \\
(\mathrm{M} / \mathrm{L})\end{array}$ & $\begin{array}{l}\text { H. B }(\mathrm{X} \pm \mathrm{S} \text {. } \\
\text { E) }\end{array}$ & $\begin{array}{l}\text { Weight } \\
(X \pm \text { S. E) }\end{array}$ & $\begin{array}{l}\text { DPK } \\
(\mathrm{M} / \mathrm{L})\end{array}$ & $\begin{array}{l}\text { H. } B(X \pm S . \\
\text { E) }\end{array}$ & $\begin{array}{l}\text { Weight } \\
(\mathrm{X} \pm \text { S. E) }\end{array}$ & $\begin{array}{l}\text { BLCO } \\
(\mathrm{M} / \mathrm{L})\end{array}$ & $\begin{array}{l}\text { H. B }(\mathrm{X} \pm \mathrm{S} \text {. } \\
\text { E) }\end{array}$ & $\begin{array}{l}\text { Weight } \\
(\mathrm{X} \pm \text { S. E) }\end{array}$ \\
\hline \multirow{4}{*}{1} & \multirow{3}{*}{0.0} & \multirow{3}{*}{$82 \pm 0.0$} & \multirow{3}{*}{$163 \pm 1.0$} & 1.0 & $83.0 \pm 0.3$ & $162.1 \pm 1.0$ & 1.0 & $84.0 \pm 1.0$ & $162.3 \pm 0.4$ & 1.0 & $85.0 \pm 0.5$ & $161.5 \pm 0.5$ \\
\hline & & & & 3.0 & $80.6 \pm 0.3$ & $102.7 \pm 0.4$ & 3.0 & $82.0 \pm 0.9$ & $100.0 \pm 0.5$ & 3.0 & $76.3 \pm 0.3$ & $96.0 \pm 1.2$ \\
\hline & & & & 5.0 & $73.3 \pm 0.3$ & $103.5 \pm 0.7$ & 5.0 & $76.7 \pm 0.7$ & $102.0 \pm 0.7$ & 5.0 & $81.0 \pm 0.5$ & $98.0 \pm 1.0$ \\
\hline & \multirow{3}{*}{0.0} & \multirow{3}{*}{$82 \pm 0.0$} & \multirow{3}{*}{$163 \pm 1.0$} & 1.0 & $93.0 \pm 0.2$ & $95.2 \pm 0.3$ & 1.0 & $83.7 \pm 1.1$ & $85.7 \pm 0.9$ & 1.0 & $67.9 \pm 0.5$ & $90.6 \pm 0.9$ \\
\hline \multirow[t]{2}{*}{24} & & & & 3.0 & $80.6 \pm 1.7$ & $90.1 \pm 0.5$ & 3.0 & $82.7 \pm 0.9$ & $95.5 \pm 0.7$ & 3.0 & $74.7 \pm 1.1$ & $90.7 \pm 1.2$ \\
\hline & & & & 5.0 & $73.6 \pm 0.6$ & $87.1 \pm 1.1$ & 5.0 & $92.2 \pm 0.6$ & $124.7 \pm 1.0$ & 5.0 & $83.2 \pm 1.5$ & $84.4 \pm 0.5$ \\
\hline \multirow{3}{*}{96} & \multirow{3}{*}{0.0} & \multirow{3}{*}{$82 \pm 0.0$} & \multirow{3}{*}{$163 \pm 1.0$} & 1.0 & $66.3 \pm 1.2$ & $104.5 \pm 0.5$ & 1.0 & $86.5 \pm 0.4$ & $103.2 \pm 0.7$ & 1.0 & $96.7 \pm 0.7$ & $85.2 \pm 0.7$ \\
\hline & & & & 3.0 & $93.6 \pm 0.5$ & $88.6 \pm 0.2$ & 3.0 & $67.1 \pm 1.5$ & $120.0 \pm 0.3$ & 3.0 & $85.0 \pm 0.3$ & $81.3 \pm 0.5$ \\
\hline & & & & 5.0 & $73.3 \pm 0.2$ & $81.2 \pm 0.5$ & 5.0 & $74.3 \pm 0.5$ & $100.1 \pm 0.5$ & 5.0 & $82.0 \pm 0.5$ & $90.5 \pm 0.9$ \\
\hline
\end{tabular}

KEY: S. E: Standard Error, H. B: Heart Beat 

Oil and Its Products on the Gill Apparatus of Catfish (Heterobranchus bidorsalis)

Table 2. Mean \pm S. E of fused gill apparatus of Heterbronchus bidorsalis exposed to different concentration of petroleum products

\begin{tabular}{|c|c|c|c|c|c|c|c|}
\hline oil & $\begin{array}{l}\text { Concentration } \\
(\mathbf{m} / \mathbf{l})\end{array}$ & $\begin{array}{l}\text { Fused lamella } \\
\text { tips }\end{array}$ & $\begin{array}{l}\text { Hyperplasia of } \\
\text { lamella }\end{array}$ & $\begin{array}{l}\text { Separation of respiratory } \\
\text { epithelium with underlying } \\
\text { supporting tissues }\end{array}$ & $\begin{array}{l}\text { Altered fine } \\
\text { branches of } \\
\text { supporting tissues }\end{array}$ & $\begin{array}{l}\text { Elongation of gill } \\
\text { lamella }\end{array}$ & $\begin{array}{l}\text { Altered gill } \\
\text { rakers }\end{array}$ \\
\hline \multirow[t]{2}{*}{ CONTROL } & 0.0 & $0.0 \pm 0.0$ & $0.0 \pm 0.0$ & $0.0 \pm 0.0$ & $0.0 \pm 0.0$ & $0.0 \pm 0.0$ & $0.0 \pm 0.0$ \\
\hline & 1.0 & $2.3 \pm 0.3$ & $5.6 \pm 0.5$ & $4.6 \pm 0.3$ & $4.6 \pm 0.3$ & $18.3 \pm 0.8$ & $5.6 \pm 0.3$ \\
\hline \multirow[t]{3}{*}{ PMS } & 3.0 & $2.6 \pm 0.3$ & $6.7 \pm 0.4$ & $5.7 \pm 0.6$ & $5.7 \pm 0.6$ & $25.1 \pm 0.5$ & $6.3 \pm 0.4$ \\
\hline & 5.0 & $4.3 \pm 0.3$ & $7.6 \pm 0.3$ & $7.1 \pm 0.3$ & $7.1 \pm 0.1$ & $32.3 \pm 0.1$ & $7.0 \pm 0.5$ \\
\hline & 1.0 & $1.3 \pm 0.3$ & $3.7 \pm 0.3$ & $2.7 \pm 0.3$ & $16.0 \pm 0.5$ & $4.7 \pm 0.3$ & $3.0 \pm 0.5$ \\
\hline \multirow{2}{*}{ DPK } & 5.0 & $3.7 \pm 0.3$ & $6.8 \pm 0.3$ & $5.3 \pm 0.3$ & $28.7 \pm 0.6$ & $6.0 \pm 0.5$ & $6.0 \pm 1.2$ \\
\hline & 1.0 & $2.7 \pm 0.3$ & $5.7 \pm 0.5$ & $4.7 \pm 0.3$ & $18.7 \pm 0.3$ & $4.7 \pm 0.7$ & $5.7 \pm 1.4$ \\
\hline \multirow[t]{2}{*}{ BLCO } & 3.0 & $2.9 \pm 0.5$ & $6.7 \pm 0.3$ & $5.7 \pm 0.3$ & $26.0 \pm 0.8$ & $6.0 \pm 0.8$ & $6.0 \pm 0.5$ \\
\hline & 5.0 & $4.7 \pm 0.5$ & $7.7 \pm 0.3$ & $7.3 \pm 0.3$ & $33.3 \pm 1.4$ & $7.0 \pm 0.8$ & $7.3 \pm 0.3$ \\
\hline
\end{tabular}

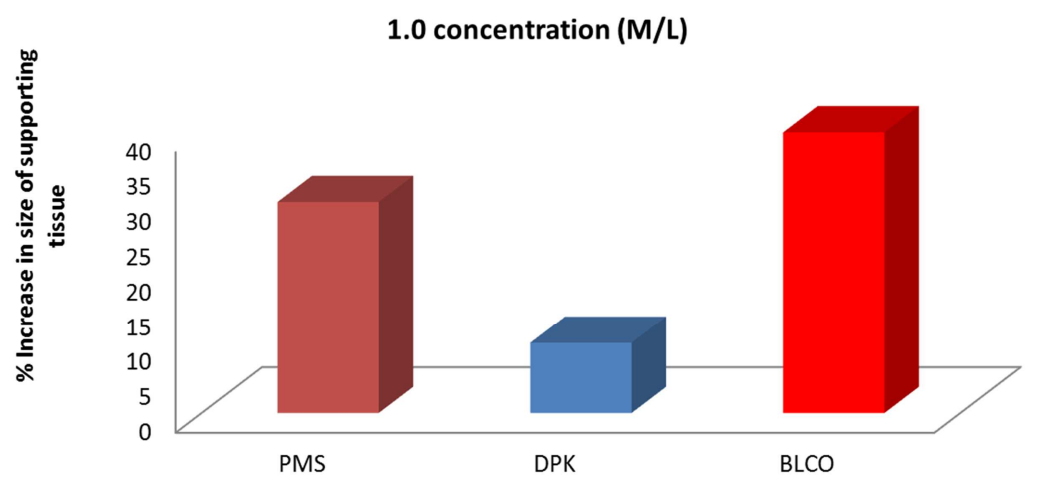

Figure 1. Percentage increase in size of underlying supporting tissues of the gill of $H$. bidorsalis exposed to $1 \mathrm{M} / \mathrm{L}$ of petroleum products.

\section{0 concentration (M/L)}
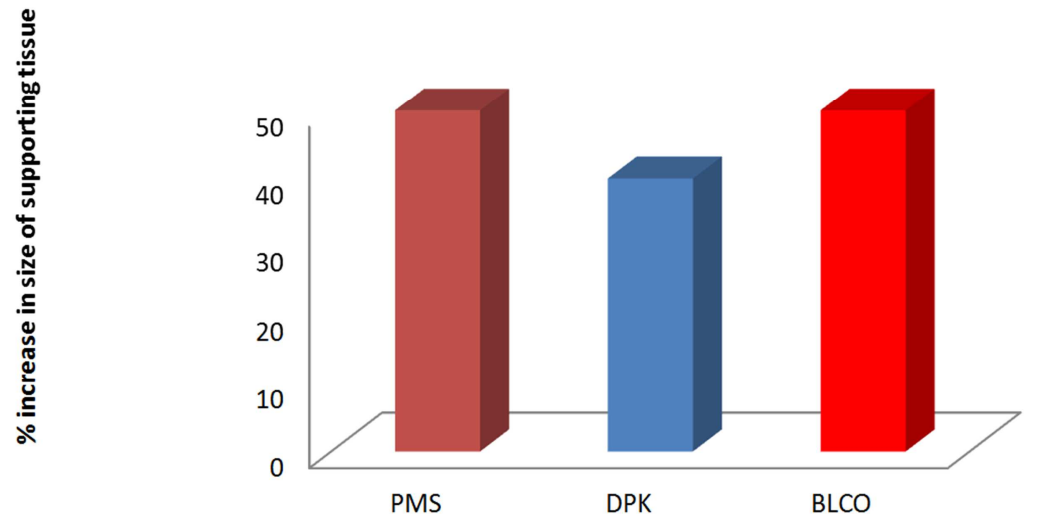

Figure 2. Percentage increase in size of underlying supporting tissues of the gill of H. bidorsalis exposed to $3 \mathrm{M} / \mathrm{L}$ of petroleum products.

\section{0 concentration $(\mathrm{M} / \mathrm{L})$}

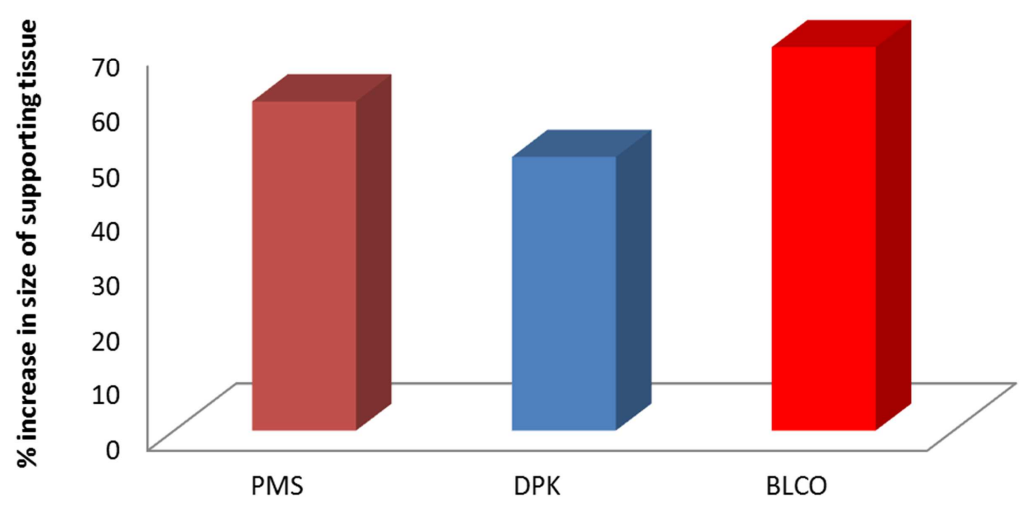

Figure 3. Percentage increase in size of underlying supporting tissues of the gill of $H$. bidorsalis exposed to $5 \mathrm{M} / \mathrm{L}$ of petroleum products. 


\section{Discussion}

The objective of the histological assessment of the gill was to verify the possible damage caused by the exposure of the fish to petroleum samples; evidencing alterations resulting from the chronic effect. The exposure of $H$. bidorsalis to petroleum products showed increased mortality even at low concentration. This agreed with [26] in their study showing that petroleum products caused damage to gill tissues and also induced fish mortality by the excessive cell proliferation and mucus production.

Test fish behavioral changes observed in this study are attributable to the presence of crude oil products, because similar changes were not observed in the control. Increase opercula movement is an indication of respiratory difficulty. The gills are respiratory surfaces for gaseous exchange but when they are blocked by an environmental toxicant, the surfaces available for gaseous exchange are reduced, resulting in respiratory difficulty. According to Reiser, et al. [27], Fish gills are one of the vital organs that are affected by petroleum products. Fish gill is an organ with a large surface area, highly sensitive to the effect of toxicant. Epidemiologists have attributed respiratory morbidity in human and some animals to crude oil pollution [28]. It was also observed that affected fishes were hanging at the water column, which is an indication of oxygen deficiency in the water. According to Peters et al. [29], petroleum products is a complex mixture of toxic compounds with wide variability of deleterious effects in human and animal studies. Other behavioral changes noticed in the exposed fish are erratic swimming, moribund movement jumping and lack of balance. This observation is similar to that of [30]. The toxic effects of petroleum used are not the same, they vary according to the components they are made up of. Considering petrol, because of its high rate of dissolution in water, the chemical components, viscosity and diffusion, it possesses the potential more than the other two products to be lethal and account for its high acute toxicity. Therefore the death of the fishes may have resulted from the little quantity that affects the rate of breathing there by leading to their death. This is in line with $[31,32]$.

Histopathological study of the gills showed structural abnormalities such as elongation of gill lamellae, fusion, separation of respiratory epithelium with underlying supporting tissue, necrosis and hyperplasia of the lamellae. This agreed with the study of [19] that refinery effluents caused gill damage in $O$. niloticus. The oxygen stress encountered by the fish which is responsible for the respiratory distress and death, was due to their inability to withstand the oxygen depletion of the water induced by the organic compounds in the water soluble fraction of the fuel. Similar oxygen stress imparted by the water soluble fraction of crude oil had been studied in the shrimp, Palaemon adspersus [33] and in the catfish Clarias gariepinus. Furthermore, the gill elongation and hyperplasia in the cultured fish may be induced by this oxygen stress.

Though there was no figure recorded for the mortality and behavior during the toxicity phase, this is attributed to loss of oxygen because the petroleum products blanketed the water surface there by reducing the rate at which oxygen diffuse into water. On the other hand this led to stress and the result of this stress is death. This confirmed the experiment of oxygen stress imparted by water-soluble fractions of petroleum carried out by [33]. In kerosene treatment, the increasing effect in the gill apparatus may not be according to the inhibition in the synthetic pathway of the fish, rather the increasing effect may have resulted due to the injury created on the gill, which multiplies as the concentration, increased. This is in line with [17]. The result showed significant difference $(\mathrm{P}<0.05)$ when compared to the control.

\section{Conclusion}

The result of this research work showed that crude oil and its products caused alterations in the gill apparatus of $H$. bidorsalis. To this effect, crude oil and its products was seen to have significant effect $(\mathrm{P}<0.05)$ on the gill apparatus such as fusion, separation of respiratory epithelium with underlying' supporting tissue, elongation of gill lamella and hyperplasia of lamella which led to mortality in $H$. bidorsalis adult. Increase in the concentration of the petroleum products caused an increase in hyperplasia of lamella. Thus from this research work, it was clearly seen that the different concentration of crude oil and it products has a significant effect $(\mathrm{P}<0.05)$ on the Histopathological structure of gill apparatus of Heterobronchus bidorsalis (cat fish).

Having considered the effect of crude oil and its products on $H$. bidorsalis as it causes alteration and damage to the gill apparatus, it is obvious that adequate control measures should be taken so as to minimize the rate at which oil pollution occurs. Petroleum products do not only have adverse effect on fish but it also has effect on everything it gets in contact with. Moreover, the effect of petroleum products on fish is much more similar to the effect in man. Therefore it is advisable that man should not expose himself to this toxicant and avoid contaminated fish.

\section{References}

[1] Abler P. H, (1985). Petroleum and Individual Polycyclic Aromatic Hydrocarbon In: Handbook of Eco-Toxicology. Lewis publishers. Boca Raton 330-355 pp.

[2] Mckay, J. M and Erickson, R. J (1991) Environmental Impact on the Physiological Mechansims Controlling Xenophobic Transfer across fish gills. Physiological Zoology 64 (1): 39-67 pp.

[3] Barron, M. G and L. Ka aihue (2001). Potentials for Toxicity of Spilled Oil in water. Marine Pollution Bulletin, 43: 86-89 pp.

[4] Sabo, D. J and Stageman, J. J (1977). Some Metabolic Effect of Petroleum Hydrocarbons in marine fish In: Physiological Response of Marine Biota to Pollutant. Academic Press, New York 279-287 pp. 
[5] Ugwu, L. L and Nwamba, H. (2004). Fish Systematic In: Introduction of Fisheries, J. T. C Publishers Enugu 6-55 pp.

[6] Raven and Johnson (1999). Vertebrates In: Biology WCB Mcfiraw Hill Fifth Edition 850-871pp.

[7] Reed, W, Burchar, J. Hopson, A, J, Jonathan J and Ibrahim I (1967). Fish and fisheries of Nigeria. Government Press London 226 pp.

[8] Hughes, G. M, (1982). An introduction to the study of gill. In: Gills. Cambridge University Press 1-24 pp.

[9] Laurent, P. and Perry, SF (1992) Environmental Effect on fish gill Morphology. Physiological zoology. 64 (1): 4-25 pp.

[10] Randall, D. (1982). Blood flow through gills. In: Gills Cambridge University Press 173:- 192 pp.

[11] Baudo, R. and Muntau, H. (1990), Lesser Known inplace pollutants and diffuse source problems. In: Baudo, R.; Giesy, J. P. and Muntau, H. Sediments: chemistry and toxicity of inplace pollutants. Boca Raton, Lewis Publishers, Inc. 1, 1-14.

[12] Rand, G. M and Petrocelli, S. R (1985). Fundamentals of Aquatic Toxicology method and Application London, Hemisphere Publishing Corporation Cap. 1: 1-28pp.

[13] Rankin, J. C. Stage, R. M. and Bolisil, L (1982). Effect of Pollutants on Gills. In: Gills. Cambridge University Press 207 $-220 \mathrm{pp}$.

[14] Nowak, B (1992). Histological changes in gills induced by Residues of Petroleum. Aquatic Toxicology. 23: 65-85 pp.

[15] Tundisi, J. G Matsumura- Tundisi, T and Rocha O. (1999) Theoretical Basis for Reservoir Management. In: Theoretical Reservoir Ecological and its Application. 505-528 pp.

[16] Hollis, L and Playle, R. C. (1997). Influence of Dissolved Organic Compound of petroleum on Gills of Rainbow trout. Journal of Fish Biology. 50, 703-720 pp.

[17] Gerade, H. W (1959). Toxicological studies on HydrocarbonsKerosene. Toxicology and Applied Pharmacology 1 (5): 462474pp.

[18] Kiihnhold W. W. (1980). Some aspect of the impact of Aquatic Oil Pollution on Fishery Resources. FAO/UNDP South China Sea fisheries. Development and coordinating programme. Manilla, Philippines 1-26pp.

[19] Oladimeji, A. A and Onwumere, B. G (1988). Sub-lethal Effect of Treated Effluents from the NNPC Refinery Kaduna to Oreochromis niloticus (tilapia). The Petroleum Industry and Nigeria Environment 256-762 pp.
[20] Bettex-Galland, M. and Hughes G. M (1973). Contractile filament is in the pillar cells of fish gills. Journal of cell. Sci. 13, 359-37 0pp.

[21] Karlsson-Norrgren, L. and Runn, P. (1985) Petroleum Induced Changes in gill Morphology of Zebra fish and rainbow trout. Journal fish Biology 27, 189-206pp.

[22] Ewald, G. (1995). Chronic measures of Toxicant Induced Effects on fish. Ann. Zoo1. 32: 311-316pp.

[23] Mallrat, J. (1985). Fish gill structural changes induced by Toxicants and other Irritants: a Statistical Review ca. Journal Fish Aquatic Science. 42, 630-648 pp.

[24] Peleksic, V. and Mitrovic- Tutundizic V. (1994). Fish gills Monitor of sub-lethal and chronic effects of pollution. In: Sublethal and chronic Effect of pollutants on fresh water fish. United Nation Fishing News Book. 339-352pp.

[25] Peter, H. R and George, B. J. (1999). Respiration in Biology. Fifth Edition. Me Graw Hill Company 973-977 pp.

[26] Afolabi O. A, Adeyemi S. A and Imevbore, (1985). Studies on Toxicity of Some Nigeria Crude Oil to some Aquatic Organism, In: proc. of 1985 instep on the Petroleum Industry and the Nigeria Environment held at Kaduna.

[27] Reiser, S. Schroeder, I. P. Wuertz, S. Kloas, W. and Hanel R. (2010). Histological physiological alterations in Juvenile corbot (Psetta maxima) exposed to sublethal concentrations of ozone produced oxidant. Aquaculture 307: 157-164.

[28] Mittleman, M. A. (2004). Air pollution, exercise, and cardiovascular risk. N Engl J Med; 357: 1147-9.

[29] Peters, A. von Klot, S. and Heier M. (2004). Exposure to traffic and the onset of myocardial infarction. N. Engl. J. Med. 351: 1721-30.

[30] Ogundiran MA, Fawole OO, Adewoye SO, Ayandiran TA. (2009). Pathologic lesions in the gills of Claria gariepinus exposed to sublethal consecrations of soaps and detergent effluent. Journal on Cell and Animal Biology. 3 (5): 078082.3.

[31] Baker, J. M (1971). Seasonal Effect of Oil Pollution on Littoral Community. Ed Cowell, E. B Institute of petroleum London 44-51 pp.

[32] Crapp, G. B (1971) Laboratory Experiment with Emulsifiers. In: the Ecological Effect of Pollution on Littoral Communities. Ed Cowell E. B Institute Petroleum London 129-149 pp.

[33] Baden S. P, (1982). Oxygen Consumption Rate of shrimp exposed to make Oil extracts. Marine, pollution. Bulletin. 13 (7): $230-2333 \mathrm{pp}$ 